\title{
HBIM FOR THE SEISMIC VULNERABILITY ASSESSMENT OF TRADITIONAL BELL TOWERS
}

\author{
A. Mondello ${ }^{1}$, R. Garozzo ${ }^{1}$, A. Salemi ${ }^{1}$, C. Santagati ${ }^{1 *}$ \\ ${ }^{1}$ Department of Civil Engineering and Architecture, University of Catania, via Santa Sofia 64, 95123, Catania, Italy \\ amondello@darc.unict.it, raissa.garozzo@unict.it, asalemi@dau.unict.it, cettina.santagati@dau.unict.it
}

\section{Commission II, WG II/8}

KEY WORDS: H-BIM, Photogrammetry, Historic bell towers, Traditional building techniques, Seismic vulnerability, Risk assessment

\begin{abstract}
:
The research proposes a novel and expeditious approach starting from direct and SfM (Structure from Motion) surveying up to H-BIM to provide a supporting tool to the knowledge of traditional bell towers, also useful for the seismic vulnerability assessment. The research draws on the possibility to enrich the H-BIM model with a semantic layer that takes into account the vulnerability indicators as defined in 2011 Italian Guidelines for the assessment and reduction of seismic risk of cultural heritage. Starting from 3D data survey, passing through the historical and constructive analysis, and the semantic classification of parts, the workflow foresaw the setting up of a semantic layer creating parameters to be assigned to each architectural component of the building and according an expeditious check-list which focuses on empirical knowledge of bell towers. This kind of information stored in the model could be very useful in situations that require particularly timely decision-making, such as in the case of calamitous events.
\end{abstract}

\section{INTRODUCTION}

The traditional bell towers mark the historic European centres, representing an urban landscape icon and an identifying symbol for the inhabitants. Because of the high verticality, these monuments are always exposed to different risks, threatening their survival. The recent seismic events in Central Italy (like in 2016 in Accumoli) and Eastern Sicily (in 2018 in PennisiAcireale) have once again shown the extreme vulnerability of these buildings, often poorly investigated and considered only as a service area of the related churches. This vulnerability poses a threat both to public safety and to the preservation of cultural, material and technological evidence of historical and architectural heritage. In agreement with the shared methodological approach of architectural restoration, the Italian legislation has officially declared the importance of an in-depth cognitive path as a prerequisite for any assessment of vulnerability and seismic improvement intervention, via the 2011 Italian Guidelines for the seismic risk assessment of cultural heritage. All this is to avoid incorrect evaluations or oversized and invasive consolidation works. This cognitive path must necessarily begin with the preliminary knowledge of the "corpus" of the building, the construction phases analysis and from the empirical observation (Doglioni et al., 1994), translated into terms of geometric and technical-constructive surveys.

Thanks to the architectural survey and the empirical observation of the building, we can identify the most obvious critical issues about wrong geometric configurations or building techniques that can affect the structural behaviour and survival of traditional bell towers.

The seismic vulnerability assessment according to the 2011 Guidelines passes through the preliminary identification of the "vulnerability indicators", defined as "typological and constructive details that play a key role in the seismic response of the structure".

The present study takes up the results of recent research (Mondello, 2019) that has studied the geometrical configurations and building techniques of the traditional bell towers in the Eastern Sicily. The research designed a quick check-list for the main "vulnerability indicators" and anti-seismic devices identification in the bell towers. These indicators can be deducible from the carried-out surveys or from the analysis of Italian Risk Map (by the Higher Institute for Conservation and Restoration).

The aim of the research is to adopt an H-BIM approach starting from 3D data survey (Brumana et al., 2017) for the knowledge, maintaining and management of the traditional bell towers, with the information useful for the preliminary evaluation of seismic vulnerability. Therefore, the above-mentioned quick check-list has provided the basis to add a semantic layer for each component of the building, storing information that could be useful in situations that require particularly timely decisionmaking, such as in the case of calamitous events.

This methodology has been tested on the bell tower of the San Giuseppe church (18th century) in Aci Castello, near Catania, an area subject to both seismic and volcanic risks. The research starts from the necessary historical-archival investigations and then carries out an architectural and material survey, identifying any inherent vulnerabilities in geometric configurations and building techniques.

The paper is structured as follows: section 2 will deal with the analysis of the state of the art; section 3 will describe the methodology of the research from the 2011 Italian Guidelines to the Informative model; section 4 will apply the methodology on a chosen case study; section 5 will discuss future works and conclusion.

\footnotetext{
* Corresponding author
} 


\section{STATE OF THE ART}

\subsection{Traditional bell towers: a built heritage at risk}

After the disastrous earthquakes that hit the Italian territory between the $70 \mathrm{~s}$ and 80 s of the 20th century, the theme of the seismic vulnerability of the built heritage has been increasingly deepened. This research was officially inaugurated by Antonino Giuffrè who, since 1986, has conducted several studies on seismic vulnerability analyses intended as a damage prediction study (Donatelli, 2010) starting from the empirical observation of historic buildings hit by seismic events. This approach is based on empirical knowledge that the masonry is not characterized by a global behaviour that enables the spread of the stresses, so these structures under seismic action reach the point of collapse due to the loss of equilibrium of limited portions called "macroelements". The kinematic models describing the process of the macroelement discretization and the related displacements are known as "damage mechanisms". From this, it follows the need for a careful study of recurring seismic pathologies in the historic buildings, mainly based on direct observation of the phenomena (Giuffrè, 1993).

The first organic study of historic monumental buildings is Francesco Doglioni's research on the churches ruined by the 1976 Friuli earthquake. This study is the basis of all the literature about this topic still today. Through the empirical approach, the research has pointed out two macroelements for the bell towers: the "tower" and the "bell cell". For each of these there are many recurring damage mechanisms (Doglioni et al., 1994). Thanks to this study and other empirical researches (Blasi, 2013), we can say that the tower macroelement can suffer damage mechanisms like rotations or translations to the outside of the top or of the corners. As for the bell cell, the main damage mechanisms are especially overturnings caused by rotating, sliding of the piers and the overturning of the spires for shear failure or buckling. The damage mechanisms are also influenced by the position of the bell towers compared to the church. Many empirical studies make a type classification of the belfries as: isolated, with no contact with other parts of the building; leaning bell towers, whose contact zones are extended to a maximum of two sides; merged bell towers, with contact zones extended to three or in all contact areas; overlapped to the building church (Mondello, 2017; Di Tommaso, Casacci, 2013; Doglioni et al., 1994).

In the wake of these researches, several studies have recently dealt with the seismic vulnerability of the Italian turreted historical heritage. Among the most relevant studies, we note the one on the bell towers of Piedmont (Dezzi Bardeschi et al., 2017) and especially the research about the census, the structural behaviour and vulnerability assessment of the Venice belfries (Lionello, 2013). This study detected the cracks systems of the bell towers and aimed to identify the damage mechanisms able to explain the kinematic instabilities, as well as identifying the possible actions of rehabilitation. The most recurrent damage mechanisms in the macroelements, identified by the Doglioni research group, have been integrated into special abacus by the Italian legislation, that has incorporated the cinematic approach as opposed to the global approaches to evaluate the safety of historic buildings. This to avoid generic computational models that oversimplify reality and has led to incorrect design choices in the recovery actions of the past, which often proved to be unnecessary, overly invasive and not very compatible with the traditional building. Indeed, the approach suggested to designers for the seismic vulnerability evaluation (and the subsequent restoration works) is based on different levels of gradually more detailed knowledge: LV1 for territorial-scale assessments of all protected cultural heritage; LV2 for assessments in relation to local interventions on limited parts of the building, performing only kinematic analysis of the macroelements; LV3 for the design of interventions that affect the overall structural behaviour or when an accurate global seismic evaluation of the building is required (Della Torre, 2016). For this reason, the 2011 Guidelines try to mitigate the achievement of seismic improvement with the cultural value of the monument. To respect this value, a deep "anamnesis" of the "corpus" of the building is necessary; this is especially true in the case of bell towers with several construction phases and with the use of different workers and materials (Di Tommaso, Casacci, 2013). As already mentioned, starting from the LV1 evaluation level, for each of the 28 possible damage mechanisms, associated with the different macro elements recognizable in the churches, the Guidelines suggest preliminarily identifying the "vulnerability indicators", defined as "typological and constructive details that play a key role in the seismic response of the structure". The knowledge of these indicators is necessary since the LV1 assessment, in which a numerical score based on the degree of severity is assigned to each vulnerability indicator detected. These scores combine to obtain a numerical vulnerability index of the macro-element on a statistical basis.

\subsection{From survey of tall buildings to H-BIM}

Photogrammetry and Terrestrial Laser Scanning (TLS) are widely employed techniques to acquire geometric/spatial data in the field of Cultural Heritage (Dore, Murphy, 2017; Bertocci, Bini, 2012; Bianchini 2007). According to the condition of the object to be surveyed, the time and the economic resources available, the Structure from Motion (SfM) photogrammetric approach has become very popular, due to its affordability, automation and reliability (Morandi, Tremari, 2019; Chiabrando, Spanò, 2013). The survey of buildings characterized by a geometric configuration with strong verticality, such as bell towers, can be challenging, especially using image-based methods. Quite often, the acquisition point is placed on the ground and/or very close to the tower, so it could be very difficult to survey higher parts, because of the distance and the projections. In such a case, the use of UAV (Unmanned Aerial Vehicle) is a valid method for the low-cost data acquisition of vertical structures, complex or difficult to access architectures (Alicandro, Rotilio, 2019; Parrinello et al., 2019; Jo, Hong, 2019). During the interior survey, other issues arise: quite often the staircases are too dark and barely artificially illuminated; in addition, the narrow space makes really complicated to get the right overlap of images. In this case, a wide range of experiments have been carried out on the use of fisheye lenses and panoramic cameras, for speeding up the survey phase and designing a complete photogrammetric survey of this type of spaces. (Clini et al., 2019; Covas et al., 2015).

The 3D data survey can be used as a basis for the creation of a HBIM (Historic/Heritage Building Information Modelling), useful, for instance, for the knowledge, maintaining and management of buildings (Brumana et al., 2017; Tommasi et al., 2016). Applying BIM approaches to historical buildings means exploiting the potential of parametric modelling and the accuracy of reality-based surveys at once (Di Luggo, Scandura, 2016). One of the main advantages is the possibility to implemented and updated the database with new information. The parametric 
approach, therefore, allows to modify the level of details of the modelled object depending on new information available about it (e.g. through non-destructive tests) (Bruno, Fatiguso, 2018; Oreni et al., 2017; Stober et al., 2018). The transition from discrete three-dimensional model of point clouds to an infographic model, involves simplifications and deductive assumptions. Because of that, some interesting studies (Santagati, Lo Turco 2017; Biagini et al., 2016) using different approaches to convert point clouds into parametric objects, introducing the concept of "level of accuracy". The definition of the level of geometric accuracy, in terms of adherence between the numerical model and its geometric abstraction, could be substantially complex in the presence of damaged or ruined architecture (Garozzo et al., 2019). The proper importance could be given, furthermore, at the valorization of the survey data, through the measurement of the Level of Reliability (Nicastro, 2018), related to data conversion issues and to the Level of Graphic and Informative Detail (LoG and LoI), according to the (UNI 11337: 2017) (Lo Turco et al., 2018).

\section{FROM THE 2011 ITALIAN GUIDELINES TO THE INFORMATIVE MODEL}

As already mentioned, a recent study (Mondello, 2019) investigated the bell towers in the Etna area, a region exposed to seismic and volcanic risk. The research has conducted a census of the existing masonry towers (never previously carried out) and a typological classification according to the position of the tower with regard to the church building and following the categories proposed by empirical studies about historical churches subject to seismic risk. Then, the study has selected some case studies, emblematic for the area and dating back to the 17th and 18th centuries. For these cases, the study has conducted architectural and technical-constructive surveys, also with the help of SfM methods like in other studies (Sammartano, Spanò, 2017; Mirabella Roberti, 2017), to recognise the most recurrent geometric configurations, the building techniques and the possible intrinsic criticalities hidden in them. Thanks to the indepth study of these cases, the on-site surveys, the typological census and the consultation of the Italian Risk Maps of Cultural Heritage, the research was able to develop and propose a checklist of the main seismic vulnerability indicators in the 158 founded specimens (Fig. 1).

This check-list perfectly follows the 2011 Guidelines and can be generally applied to bell towers in any area subject to seismic risk. In this list, the indicators are subdivided according to the two macroelements "tower" and "bell cell" and they are classified according to two different categories: indicators linked to the geometric configurations of the building and indicators linked to specific building techniques. The existence of even one of these indicators can suggest a possible damage mechanism for the macroelement. For the geometric aspects, in the "tower" macroelement, the vulnerability indicators are linked to the building type, considering any adjacent buildings as asymmetrical constraints for the macroelement (with which they can have shared walls).

Empirical studies have also shown how the internal planimetric layout can influence structural behaviour, especially if there are vaults (Vault in ground floor) or if there are no horizontal intermediate structures (Empty tower).

\begin{tabular}{|c|c|c|c|c|c|}
\hline \multicolumn{6}{|c|}{ VULNERABILITY INDICATORS (GEOMETRY) AND POSSIBLE DAMAGE MECHANISMS } \\
\hline \multicolumn{6}{|c|}{ MACROELEMENT: TOWER } \\
\hline \multirow{2}{*}{ VULNERABILITY INDICATORS } & \multicolumn{5}{|c|}{ Possible damage mechanisms } \\
\hline & Simple overturning & Corner overturning & Hammering & \multicolumn{2}{|c|}{ Vertical strips subdivision } \\
\hline Asymmetrical constraint & $\checkmark$ & & $\checkmark$ & & \\
\hline Empty tower & $\checkmark$ & & & \multicolumn{2}{|c|}{$\checkmark$} \\
\hline Vaults in ground floor & $\checkmark$ & $\checkmark$ & $\checkmark$ & & \\
\hline Aligned openings & $\checkmark$ & & & \multicolumn{2}{|c|}{$\checkmark$} \\
\hline \multicolumn{6}{|c|}{ MACROELEMENT: BELL CELL } \\
\hline \multirow{2}{*}{ VULNERABILITY INDICATORS } & \multicolumn{5}{|c|}{ Possible damage mechanisms } \\
\hline & Simple overturning & Corner overturning & Hammering & \multicolumn{2}{|c|}{ Vertical strips subdivision } \\
\hline Slender piers & $\checkmark$ & $\checkmark$ & & & \\
\hline \multicolumn{6}{|l|}{ Discontinuous vertical walls } \\
\hline \multicolumn{6}{|c|}{ VULNERABILITY INDICATORS (BUILDING TECHNIQUES) AND POSSIBLE DAMAGE MECHANISMS } \\
\hline \multicolumn{6}{|c|}{ MACROELEMENT: BELL CELL } \\
\hline \multirow{2}{*}{ Building elements } & VULNERABILITY & \multicolumn{3}{|c|}{ Possible damage mechanisms } & \multirow{2}{*}{$\begin{array}{l}\text { Non-quantifiable } \\
\text { Vulnerabilities }\end{array}$} \\
\hline & INDICATORS & Simple overturning & Corner overturning & Hammering & \\
\hline \multirow{3}{*}{ Vertical structures } & Ineffective link & $\checkmark$ & $\checkmark$ & & \\
\hline & Type of masonry & & & & $\mathrm{v}$ \\
\hline & \begin{tabular}{|l|}
$\begin{array}{l}\text { Construction } \\
\text { discontinuity }\end{array}$ \\
\end{tabular} & $\checkmark$ & $\checkmark$ & & \\
\hline Horizontal structure & \begin{tabular}{|l} 
Rigid horizontal \\
structures
\end{tabular} & $\checkmark$ & & $\checkmark$ & \\
\hline Roof structure & Thrust type & $\checkmark$ & $\checkmark$ & & \\
\hline Support structure & $\begin{array}{l}\text { Reinforced concrete } \\
\text { structure }\end{array}$ & & & $\checkmark$ & \\
\hline \multirow{4}{*}{ Vertical stone envelope } & Projecting cornices & & & & \multirow{4}{*}{$\checkmark$} \\
\hline & Corbels and brackets & & & & \\
\hline & Pinnacles & & & & \\
\hline & Merlons & & & & \\
\hline \multirow[b]{2}{*}{ Bells } & Bells in windows & & & & $\checkmark$ \\
\hline & $\begin{array}{l}\text { Bells in external } \\
\text { frameworks }\end{array}$ & & & & $\checkmark$ \\
\hline
\end{tabular}

Figure 1. An offprint of the proposed check-list of the vulnerability indicators for the macroelements of the traditional bell towers. 
The considerable openings, aligned at the different levels, can contribute to the triggering of vertical subdivisions of the macroelement (Aligned openings). In the "bell cell" macroelement, the seismic vulnerability often depends also on the existence of slender piers, that is it depends on the considerable size of the archivolts containing the bells. Another indicator to consider is the possible existence of vertical discontinuities of the walls (Discontinuous vertical wall), that is the misalignment of walls on different levels when a wall does not rest on the underlying one.

About the technological aspects, it is possible to identify vulnerability indicators in some of the construction elements. For vertical structures, the ineffective links between the walls or the ineffective links with the underlying masonry (Construction discontinuity) are indicators of vulnerability.

The type of masonry, if it is of poor quality, can represent a "non-quantifiable" vulnerability. This category includes all the intrinsic properties of a building element or entire building elements, such as statues or other stone ornaments projecting from the facades; these can represent a risk for public safety in the event of collapse, even if they are difficult to translate into numerical analysis (Coïsson, 2013). Moreover, rigid horizontal structures, such as the reinforced concrete slabs, or other reinforced concrete structures, such as the top curbs that caused considerable damage in the last earthquakes in Italy, or pushing structure of the roof, like wooden rafters (Thrust type), are also indicators of vulnerability.

Starting from these results and the SfM survey, our research wants to prepare an informative model in H-BIM environment, that can always be updated and improved. The study wants to integrate the acquired knowledge and the check-list of seismic vulnerability indicators. So, this model can be useful in different phases of analysis: in the scheduling phase, in the time immediately following seismic events to extract data for damage assessment; in the preventive phase of vulnerability assessment with a confidence level "LV1", as required by the Guidelines; in the analytical in-depth phase to implement multidisciplinary knowledge about the building and to be able to prepare both more detailed assessment and the necessary seismic improvement design.

In this first step of our study, we considered the first part of the check-list related to the vulnerability indicators linked to the geometric configurations of the bell towers (Fig. 2) and we tested this methodology in the emblematic case of the traditional belfry of the San Giuseppe church in Aci Castello.

In order to link the geometric vulnerability indicators to the modelled bell tower, these indicators were rearranged according with the semantic subdivision made by the chosen parametric platform and converted in shared parameters.
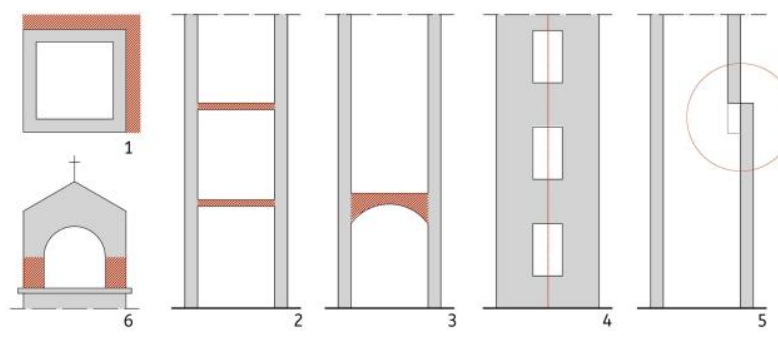

Figure 2. Explanatory schemes of geometric vulnerability indicators: 1 . asymmetrical constraint; 2 . empty tower; 3 . vault in ground floor; 4. aligned openings; 5 . discontinuous vertical wall; 6 . slender piers.
The chosen parameters are all instance parameters, as they could be assigned to individual objects even of the same type. Furthermore, yes/no and number types parameters were preferred to avoid problems in codifying information in text type parameters. Each parameter is accompanied by a brief description that help the user in the compilation.

The parameters are set as shown in the Table 1. In the following phases, it will be possible to extract the data collected in a properly prepared spreadsheet that is able to associate the possible damage mechanisms to the vulnerability indicators.

\begin{tabular}{|l|l|l|l|}
\hline Indicator & Parameter & Category & Par. Type \\
\hline $\begin{array}{l}\text { Asymmetrical } \\
\text { constrain } \\
\text { Empty tower }\end{array}$ & Shared wall & Wall & Y/N \\
$\begin{array}{l}\text { Vault in ground } \\
\text { floor }\end{array}$ & Level & Wall & Y/N \\
Aligned openings & Aligned openings & Wall & Y/N \\
Slender piers & Slenderness & Column & Y/N \\
$\begin{array}{l}\text { Discontinuous } \\
\text { vertical wall }\end{array}$ & $\begin{array}{l}\text { Discontinuous } \\
\text { wall }\end{array}$ & Wall & Y/N \\
\hline
\end{tabular}

Table 1. The indicator-based parameters settings.

\section{CASE STUDY}

The church of San Giuseppe is located at the eastern end of the historic centre of Aci Castello, a small town on the Ionian coast of the Etna area (Fig. 3). The church and its bell tower were built around 1740, although the lower part of the tower may be older than the bell cell, which is certainly from the 18th century. In 1908 , the tower suffered the demolition of the original majolica cusp crowning the bell cell.

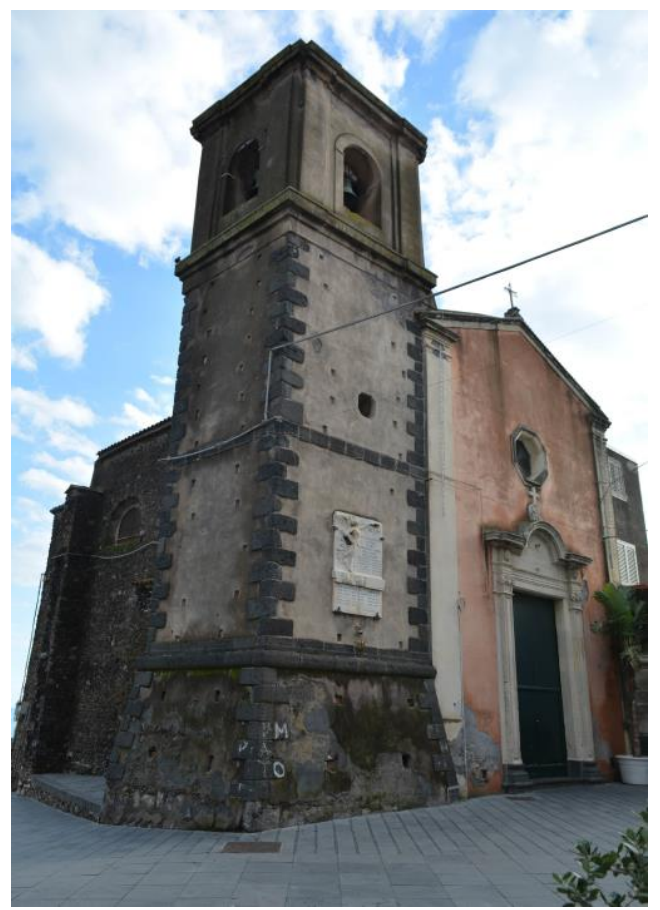

Figure 3. The church of San Giuseppe in Aci Castello (Catania). 


\subsection{Formal and geometrical aspects}

The church of San Giuseppe has a rectangular single hall, oriented from west to east, and a polygonal apse behind the neighbouring panoramic coastal road. The bell tower is in the north-western corner of the church, in line with the main façade and leaning against the northern face of the nave.

The tower has rectangular plan with a truncated pyramid-shaped base; this is 2.60 meters high and its external dimensions are equal to 4.40 meters by 4.00 meters at the base. Above the base, the body of the tower is about 10.50 meters high, with a rectangular plan of 3.75 meters by 3.26 meters. Above this macroelement is the bell cell, which is 4.20 meters high. This has quadrangular plan (2.40 meters by 1.82 meters) and is surmounted by a square crowning on little protruding pilasters. Base and tower are delimited by stone corners.

The tower fronts are divided into two parts by a square stringcourse at an altitude of about 6.16 meters. The only openings existing in the San Giuseppe bell tower are the round arches in central position in the north, east and west fronts of the bell cell. Two of these archivolts house the bells. The bell tower is accessible only from the nave. The inner space is narrow, with a rectangular plan (3.00 meters by 1.70 meters). This space is surmounted by a barrel vault with a lowered arch at the height of 10.00 meters. The tower houses the staircases on rampant vaults with ten stair flights.

\subsection{Materials and building techniques}

The recognition of the materials and the building techniques employed in the San Giuseppe bell tower was possible thanks to specific direct surveys and the analysis of the photos of the 1979 restoration works. The building is fully consistent with the recurrent traditional building techniques of the Etna area (Salemi, 2018).

As for the vertical bearing structures, thanks to the inspection of the inner spaces of the tower, we have easily identified the masonry in irregular basaltic stones (with a very variable size), fragments of bricks and lime mortar and "azolo" (a volcanic aggregate). In this masonry, every 0.80 meters or 1.20 meters, there are regularization planes in fragments of brick or pressed bricks and lime mortar and "ghiara" (another volcanic aggregate). The walls of the tower base have a maximum thickness of 1.20 meters, while the thickness of the elevation walls ranges between 0.70 meters and 0.80 meters. The piers of the bell cell are characterized by a more heterogeneous masonry, with irregular stones mixed with roughly squared ashlars and pressed bricks.

As already mentioned, the nave and the body of the tower have a shared wall. The southern wall of the bell cell was not built on the underlying wall, but it is on an archivolt leaning against the aforementioned wall shared by the tower and the nave. This archivolt has a depth of about 70 centimetres and it is made up of several concentric rings of irregular stone elements in bullous basalt (with dimensions of $25 \times 17 \times 5$ centimetres) linked by lime mortar and "azolo" (archivolt "in concretion").

The arches of the bell cell are built with volcanic and brick fragments linked by plentiful lime mortar and azolo. The barrel vault of the upper definition of the tower macroelement is made in the same way as the other archivolts and it has a minimum thickness of about $20 \mathrm{~cm}$. Similarly, the rampant vaults of the stairs are in concretion, with irregular elements in pumice stone and gypsum mortar (with a thickness between 10 and 15 centimetres). The roof of the bell cell is hipped, with a wooden truss and four rafters. Above these elements, there are the battens and the Sicilian tiles.

The external plaster of the bell tower appears to consist of a cement-based rough coat and a finishing plaster in lime mortar, volcanic aggregates and "cocciopesto". The internal plaster consists of a rough coat in lime mortar and azolo without finishing coats. As regard to the vertical stone envelope, the facades are very simple and consist of only few elements. The string course that concludes the base is characterized by moulded basaltic ashlars with a length varying between 60 and 80 centimetres. The intermediate string-course, which divides the fronts of the tower macroelement into two parts, and the corners of the tower are made up of simple basaltic ashlars, with dimensions of about $25 \times 30 \times 40$ centimetres. The base and the crowning of the bell cell, as well as the pilasters and the cornices of the arches, are instead in mortar.

\subsection{The 3D data acquisition and the H-BIM approach}

Considering the expeditious nature of the method, SfM approach was applied. However, because of the narrowness and the precarious conditions of the inner space, the interior room has been surveyed by means of direct methods. Moreover, since the bell tower is partially incorporated in the church, it was not possible to properly survey the south wall of the bell cell.

Data collection was conducted using a Nikon D5200, focal length of $27 \mathrm{~mm}$, with a resolution of $24 \mathrm{MP}$, for a total of 296 images, taken from the ground. The GDS (ground sampling distance) is $2.9 \mathrm{~mm} / \mathrm{pix}$. The photographic dataset was automatically processed with Agisoft Metashape. A first stage of cameras alignment was followed by a sparse and, then, a dense point cloud reconstruction (10.218.757 points) (Fig.4).

The dense point cloud obtained have been saved in ".ptx" format and imported in Autodesk RecapPRO to be edited. Finally, the point cloud becomes the basis to the H-BIM model. In order to better attribute the vulnerability indicators as shared parameters, the modelling was carried out with attention in some significant elements, e.g. walls, vaults and floors.

The 3D modelling of the bell tower was carried out using Autodesk Revit as a BIM platform, with the support of the Asbuilt for Revit plug-in, and the standalone software platform VirtuSurv. The creation of walls was conducted through a semiautomatic procedure using equirectangular images getting from the point cloud. This workflow allows a faster modelling, consistent with the quickness of the entire methodology. During the wall modelling phase, it has been clearly visible that

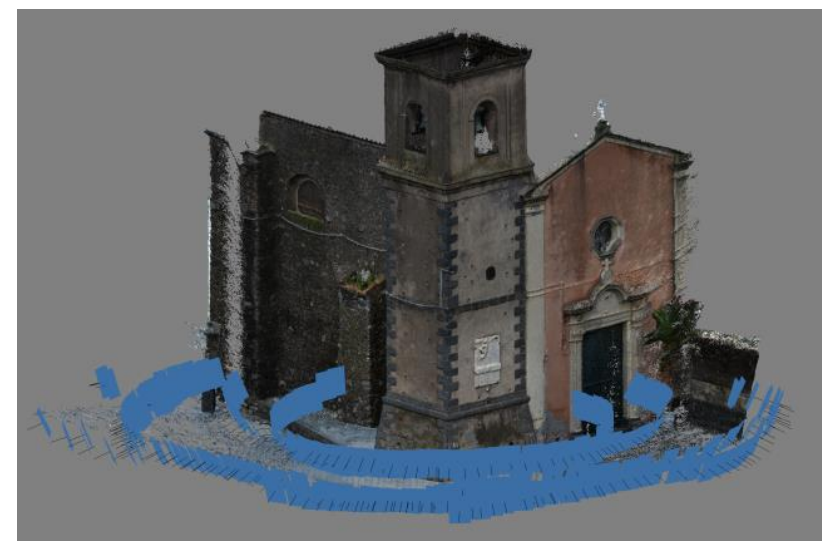

Figure 4. The point cloud obtained with a SfM photogrammetric approach. 


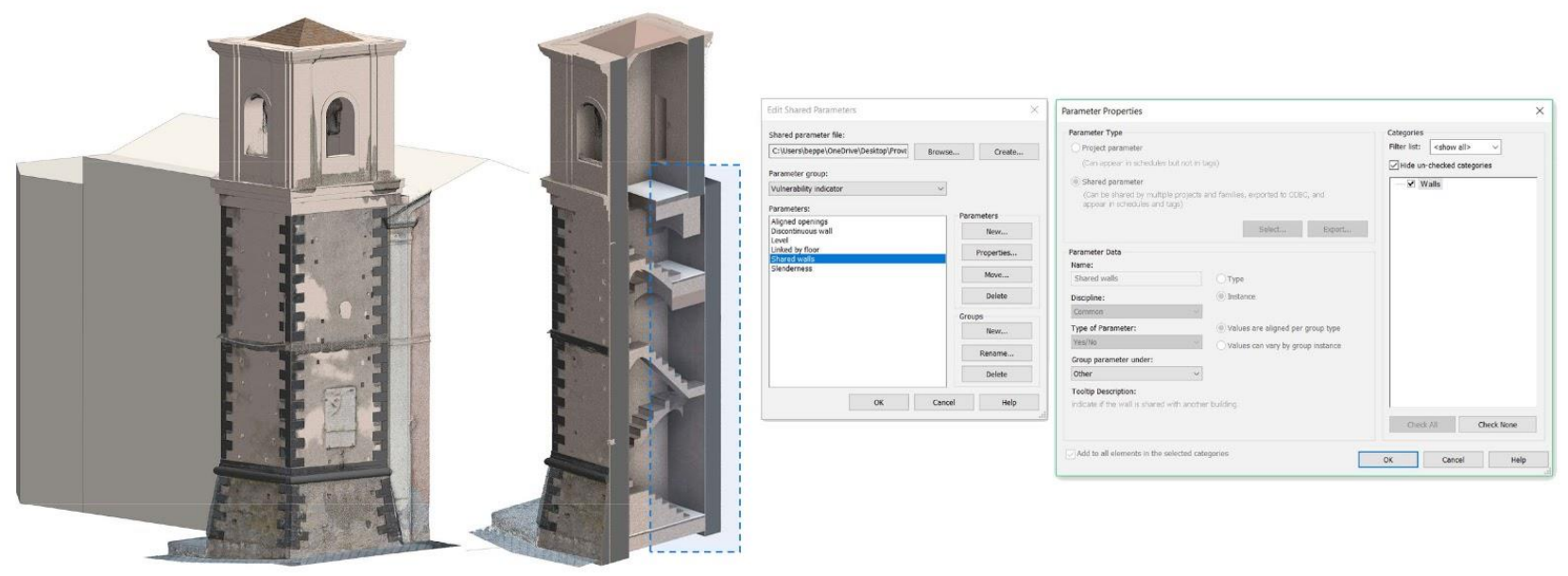

Figure 5. The HBIM of San Giuseppe bell tower superimposed on the point cloud. The shared parameters group and the parameter properties (took as an example the "shared wall" parameter) are shown on the right.

the bell cell macroelement is inclined compared to the ideal vertical axis of the tower macroelement; it has also been possible to quantify the not squared walls angles. Since modelling with a middle level of geometric accuracy was considered enough detailed for this research purposes, the bell cell walls have been modelled as wall system families in Revit, except for corner walls, shaped as columns, in order to assign them the "slenderness" parameter.

The rampant vaults of the stairs, instead, were modelled as parametric floor-based families, that can be adjusted after performing a more reliable interior survey (Fig. 5).

\subsection{Vulnerability indicators of San Giuseppe tower}

In the bell tower of San Giuseppe, we have recognized some indicators of seismic vulnerability connected to the geometric configuration of the building. The tower belongs to the type of bell tower leaning against the nave of the church; this geometric aspect conditions the seismic response of the church-belfry building system because the tower, having a shared wall with the church and being linked to the church, is not free to oscillate due to horizontal stresses. This could trigger the overturning of the highest part or the hammering of the orthogonal walls of the tower on the shared wall. The absence of horizontal intermediate structures inside the tower macroelement increases this vulnerable condition because inside the tower there are only the staircases and the only horizontal structure is the vault acting as the floor for the bell cell. As mentioned above, the surveys have shown some anomalies related to the vertical alignment of the south wall of the bell cell, which, as mentioned, is supported by an archivolt inside the building and does not rest on the underlying south wall of the nave. Due to the excessive load, probably once aggravated by the heavy upper structure demolished in 1908, the bell cell is slightly out of plumb compared to the tower macroelement. Because of this and since it is only the bell cell to rise above the church building, we can see that the most vulnerable macroelement of the tower of San Giuseppe is represented by the bell cell.

\section{CONCLUSION AND FUTURE WORKS}

The research is still ongoing and will continue with the "translation" of all vulnerability indicators into H-BIM environment and with the test of novel approaches (SLAM/fisheye/360 images) for the surveying of narrow spaces such as the interior of the bell towers.

To test the validity and the repeatability of the proposed methodology, other cases studied will be considered in other areas subjected to seismic risk.

The expeditious nature of the proposed study allows a modelling for subsequent steps based on the required degree of detail. Clearly, a "simple procedure" or a "visual query" (Ientile, 2017), also suggested by the Guidelines for the LV1 level, is not enough to fully describe neither the clinical history nor the "corpus" of monumental buildings. Aware of this, we believe however that the cognitive processes described can contribute to broadening the bases to control the built heritage according to the principles of the 2000 Cracow Charter (i.e. continuous conservation "realized by different types of interventions such as environmental control, maintenance, repair, restoration, renovation and rehabilitation"). These principles were reaffirmed with the "programmed conservation" proposed by Giuliano Urbani in the 2004 Italian Cultural Heritage and Landscape Code.

The H-BIM models, thus created, could be integrated into an interdisciplinary and geo-referenced Web-BIM platform, accessible to all the actors in the restoration process and seismic improvement, giving an overall statistic overview of the seismic vulnerability of built heritage in a certain area and according specific parameters/indicators. A final step aimed at this could be to integrate these results into the Italian Risk Maps of Cultural Heritage platform.

\section{ACKNOWLEDGEMENTS}

The research was done within a multidisciplinary collaboration, but due to the specificity of the issues addressed: paragraphs 1 and 5 were edited by A. Salemi and C. Santagati; paragraphs 2.1, 4.1, 4.2, 4.4 were edited by A. Mondello; paragraph 3 was edited by A. Mondello and R. Garozzo; paragraphs 2.2 and 4.3 were edited by R. Garozzo.

This work has been partially financed by the University of Catania within the project "Piano della Ricerca Dipartimentale 2016-2018" (COREC and Semantic projects) of the Department of Civil Engineering and Architecture. 


\section{REFERENCES}

Alicandro, M., Rotilio, M., 2019. UAV photogrammetry for resilience management in reconstruction plan of urban historical centres after seismic events. A case study. In: ISPRS International Archives of the Photogrammetry, Remote Sensing and Spatial Information Sciences, Vol. XLII-2/W11, pp. 55-61. doi.org/10.5194/isprs-archives-XLII-2-W11-55-2019

Bertocci, S., Bini, M., 2012. Manuale di rilievo architettonico e urbano. Città Studi Edizioni, Novara.

Biagini, C., Capone, P., Donato, V., Facchini, N., 2016. Towards the BIM implementation for historical building restoration sites. In: Automation in Construction, n. 71, pp. 74-86. doi.org/10.1016/j.autcon.2016.03.003

Bianchini, C., 2007. Laser Scanning X. In: P. Paolini, E. Chiavoni (eds.), Metodi e tecniche integrate di rilevamento per la realizzazione di modelli virtuali dell'architettura della città. Gangemi Editore, Roma, pp. 24-31.

Blasi, C. (ed.), 2013. Architettura storica e terremoti. Protocolli operativi per la conoscenza e la tutela. Wolters Kluwer Italia, Milanofiori Assago.

Brumana R., Della Torre, S., Oreni, D., Previtali, M., Cantini, L., Barazzetti, L., Franchia, A., Banfi, F., 2017. HBIM challenge among the paradigm of complexity, tools and preservation: the basilica di Collemaggio 8 years after the earthquake (L'Aquila). In: ISPRS - International Archives of the Photogrammetry, Remote Sensing and Spatial Information Sciences, Vol. XLII2/W5, pp. 97-104.

doi.org/10.5194/isprs-archives-XLII-2-W5-97-2017

Bruno, S., Fatiguso, F., 2018. Building conditions assessment of built heritage in historic building information modeling. In: International Journal of Sustainable Development and Planning. Vol. 13 (1), pp. 36-48.

doi.org/10.2495/SDP-V13-N1-36-48

Chiabrando, F., Spanò, A., 2013. Points Clouds generation using TLS and Dense-Matching techniques. A test on approachable accuracies of different tools. In: ISPRS Annals of the Photogrammetry, Remote Sensing and Spatial Information Sciences, Vol. II-5/W1, pp.67-72.

doi.org/10.5194/isprsannals-II-5-W1-67-2013

Clini, P., Nespeca, R., Angeloni, R., and Mammoli, R., 2019. The integrated survey of narrow spaces and underground architecture: the case study of campana caves bas-reliefs. In: ISPRS - The International Archives of the Photogrammetry, Remote Sensing and Spatial Information Sciences, Vol. XLII2/W9, pp. 277-282.

doi.org/10.5194/isprs-archives-XLII-2-W9-277-2019

Coïsson, E., 2013. Vulnerabilità non quantificabili. In C. Blasi (ed.) Architettura storica e terremoti. Protocolli operativi per la conoscenza e la tutela. Wolters Kluwer Italia, Milanofiori Assago, pp. 90-97.

Covas, J., Ferreira, V. and Mateus, L., 2015. 3D reconstruction with fisheye images strategies to survey complex heritage buildings. In: 2015 Digital Heritage, Granada, 2015, pp. 123126.

doi.org/10.1109/DigitalHeritage.2015.7413850

Cultural Heritage and Landscape Code, Italian Legislative Decree 42/2004.

Della Torre, S., 2016. Terremoto e prevenzione. ANANKE, n. 79, pp. 4-7.

Dezzi Bardeschi, M., Ientile, R., Devoti, C., Sammartano, G., Spanò, A., Naretto, M., Lupo, F., 2017. In: Architetture verticali $e$ vulnerabilità sismica. Torri e campanili in Piemonte, Altralinea Edizioni s.r.l., Firenze.

Di Luggo, A., Scandurra, S. (2016), La traduzione dal modello discreto al modello parametrico per la conoscenza del patrimonio architettonico nei sistemi HBIM, In: DisegnareCon, Vol 9, n. 16.

Direttiva del Presidente del Consiglio dei Ministri 09 febbraio 2011 (Supplemento Ordinario n. 54 della G.U. 47 del 26/02/2011), Linee Guida per la valutazione e riduzione del rischio sismico del patrimonio culturale con riferimento alle Norme tecniche per le costruzioni di cui al decreto del Ministero delle infrastrutture e dei trasporti del 14 gennaio 2008.

Di Tommaso, A., Casacci, S., 2013. Sopravvivenza di torri e campanili in ambiente sismico. In: Atti del Seminario internazionale sull'evoluzione nella sperimentazione per le costruzioni (CIAS 2013), Creta, pp. 95-118.

Doglioni, F., Moretti, A., Petrini, V., 1994. Le chiese e il terremoto. Dalla vulnerabilità constatata nel terremoto del Friuli al miglioramento antisismico nel restauro, verso una politica di prevenzione. Edizioni LINT, Trieste.

Donatelli, A., 2010. Terremoto e architettura storica. Prevenire l'emergenza. Gangemi Editore, Roma.

Dore, C., Murphy, M., 2017. Current state of the art Historic Building Information Modelling. In: ISPRS - International Archives of the Photogrammetry, Remote Sensing and Spatial Information Sciences. Vol. XLII-2/W5, pp. 185-192. doi.org/10.5194/isprs-archives-XLII-2-W5-185-2017

Garozzo, R., Lo Turco, M., and Santagati, C., 2019. Information Models to Manage Complexity for an Integrated Knowledge Project. In: diségno, n. 4, pp. 225-236.

doi.org/10.26375/disegno.4.2019.21

Giuffrè, A., 1993. Sicurezza e conservazione dei centri storici. Il caso Ortigia. Editori Laterza, Bari.

Ientile, R., 2017. I campanili di Nostra Signora della Stella a Trana, San Giacomo a Tavernette di Cumiana, San Gervaso a Costa di Cumiana e la torre di Frossasco. In: Dezzi Bardeschi, M., Ientile, R., Devoti, C., Sammartano, G., Spanò, A., Naretto, M., Lupo, F., 2017: Architetture verticali e vulnerabilità sismica. Torri e campanili in Piemonte, Altralinea Edizioni s.r.1., Firenze, pp. 62-111. 
Italian Higher Institute for Conservation and Restoration, 2009. Risk Map of Cultural Heritage.

Lionello, A., 2013. Tecniche costruttive, dissesti $e$ consolidamenti dei campanili di Venezia. Corbo e Fiore, Venezia.

Lo Turco, M., Parisi, P., Gómez-Blanco Pontes, A., Rivas López, E. J., 2018. Modelli HBIM per la valorizzazione e gestione del patrimonio culturale. Il caso studio dell'Escuela Tecnica Superior de Arquitectura di Granada, In: F. Minutoli (Ed.), Atti del VI Convegno Internazionale sulla Documentazione, Conservazione e Recupero del Patrimonio Architettonico e sulla Tutela Paesaggistica ReUSO 2018. L'intreccio dei saperi per rispettare il passato interpretare il presente salvaguardare il futuro. Messina, 11-13 ottobre 2018, Gangemi editore, Roma, pp. 2519-2530.

Mirabella Roberti, G., 2017. Diagnosi dei dissesti e conoscenza costruttiva dell'edificio: una dialettica produttiva. In: D. Fiorani and A. Grimoldi (Eds.), RICerca/REStauro, Sezione 2A: Conoscenza dell'edificio: metodo e contenuti. Edizioni Quasar, Roma, pp. 390-397.

Mondello, A., 2019. Torri campanarie degli edifici ecclesiastici tradizionali allo specchio tra conoscenza e sicurezza. Tecnologia e forma negli areali a rischio della Sicilia orientale e della Castilla y León. PhD Thesis in Evaluation and mitigation of urban and land risks, XXXI cycle, University of Catania, Supervisor Prof. Angelo Salemi.

Mondello, A., 2017. Traditional bell towers: knowledge and safety in two compared areas. In: Tema: Technology, Engineering, Materials and Architecture, Vol. 3, n. 2, pp. 124135. doi.org/10.17410/tema.v3i2.147

Morandi, S., Tremari, M., 2019. Virtual past. interactive presentation of late roman towers (archaeological museum, Milan Italy). In: ISPRS - International Archives of the Photogrammetry, Remote Sensing and Spatial Information Sciences. Vol. XLII-2/W11, pp. 887-893.

doi.org/10.5194/isprs-archives-XLII-2-W11-887-2019

Nicastro, S., 2018. L'integrazione dei sistemi di Building Information Modeling nei processi di conoscenza del Patrimonio Culturale. Premesse teoriche, criteri metodologici $e$ introduzione del Level of Reliability. PhD Thesis, Sapienza University of Rome, Supervisor Prof. Carlo Bianchini.

Oreni, D., Brumana, R., Della Torre, S., and Banfi, F., 2017. Survey, HBIM and conservation plan of a monumental building damaged by earthquake. In: ISPRS - International Archives of the Photogrammetry, Remote Sensing and Spatial Information Sciences, XLII-5/W1, pp. 337-342.

doi.org/10.5194/isprs-archives-XLII-5-W1-337-2017

Parrinello, S., Picchio, F., De Marco, R., 2019. Documentation systems for an urban renewal proposal in developing territories: the digitalization project of Bethlehem Historical Center. In: Proceedings of 2018 IEEE International Conference MetroArcheo 2018 Cassino, pp. 211-216.
Perfetti, L., Polari, C., Fassi, F., Troisi, S., Baiocchi, V., Del Pizzo, S., Giannone, F., Barazzetti, L., Previtali, M., Roncoroni, F., 2018. Fisheye Photogrammetry to Survey Narrow Spaces. In: Architecture and a Hypogea Environment. doi.org/10.3390/books978-3-03842-685-1-1

Salemi, A., 2018. Le cortine del centro storico di Catania. Materiali, forma e immagine urbana. Edizioni Efesto, Roma

Sammartano, G., Spanò, A., 2017. Metodi fotogrammetrici speditivi e low-cost per la generazione di modelli 3D di strutture verticali. In: Dezzi Bardeschi, M., Ientile, R., Devoti, C., Sammartano, G., Spanò, A., Naretto, M., Lupo, F., 2017: Architetture verticali e vulnerabilità sismica. Torri e campanili in Piemonte, Altralinea Edizioni s.r.l., Firenze. pp. 24-40.

Santagati, C., Lo Turco, M., 2017. From structure from motion to historical building information modeling: populating a semantic-aware library of architectural elements. In: Journal of Electronic Imaging, n. 26(1), pp. 011007.1-12.

doi.org/10.1117/1.JEI.26.1.011007

Stober, D., Žarnić, R., Penava, D., Turkalj Podmanicki, M., Virgej-Đurašević, R., 2018. Application of HBIM as a Research Tool for Historical Building Assessment. In: Civil Engineering Journal, Vol. 4, n. 7, pp. 1565-1574. doi.org/10.28991/cej-0309195

Tommasi, C., Achille, C., Fassi, F., 2016. From point cloud to BIM: a modelling challenge in the cultural heritage field. In: ISPRS - International Archives of the Photogrammetry, Remote Sensing and Spatial Information Sciences, Vol. XLI-B5, pp. 429-436.

doi.org/10.5194/isprs-archives-XLI-B5-429-2016

Jo, Y., Hong, S., 2019. Three-Dimensional Digital Documentation of Cultural Heritage Site Based on the Convergence of Terrestrial Laser Scanning and Unmanned Aerial Vehicle Photogrammetry. In: ISPRS - International Journal of Geo-Information, Vol. 8, n. 2, p. 53.

doi.org/10.3390/ijgi8020053

UNI (2017). UNI 11337:2017. Edilizia e opere di ingegneria civile - Gestione digitale dei processi informativi. Milano: UNI. 